\title{
The molecular characterization by SSRs reveals a new South Italian kinship and the origin of the cultivar Uva di Troia
}

\author{
C. Bergamini ${ }^{* \dagger}$, R. Perniola ${ }^{1 \dagger}$, M. F. Cardone ${ }^{1}$, M. Gasparro ${ }^{1}$, R. Pepe ${ }^{2}$, A. R. Caputo ${ }^{1 \neq}$ and D. Antonacci ${ }^{* \neq}$
}

\begin{abstract}
Vitis vinifera L. varieties were spread through cuttings following historic migrations of people, trades, or after biological crises due to pests outbreaks. Some today's varieties could be more than a 1000 years old and, although over the centuries these varieties generated most of the remaining cultivars, their origin could be impossible to track back. The Italian grapevine biodiversity is one of most important, most likely due to its strategic position in the middle of the Mediterranean sea. Unravelling of its structure is challenging because of its complexity and the lack of historical documentation. In this paper molecular data are compared with historical documentations. Simple Sequence Repeats fingerprinting are molecular markers best suited to investigate genetic relationships and identify pedigrees. SouthItalian germplasm was studied with 54 nuclear microsatellites. A family was identified, consisting of two parents and three siblings and further genetically characterized with six nuclear and five chloroplast microsatellites and described with ampelographic and phylometric analysis. Although these latter were not informative for the kinship identification. The common Bombino bianco was the female parent and the previously unknown Uva rosa antica was the male parent. Bombino nero, Impigno and the popular Uva di Troia, all typical of the south-east Italy, were the offspring. Further research showed that the Uva rosa antica was a synonym of Quagliano and Bouteillan noir, both minor varieties. Quagliano was considered to be autochthonous of some alpine valleys in the north-west of Italy and Bouteillan noir is a neglected variety of Vancluse in France. This finding uncovers the intricate nature of Italian grape cultivars, considered peculiar of an area, but possibly being the remains of ancient latin founding varieties. Consequently, intriguing new hypotheses are discussed and some conclusions are drawn, based on the peculiar geographical origin of the parents, on the distribution of the offspring, on the chance of a single, and perhaps intentional, crossing event.
\end{abstract}

Keywords: Grapevine, Uva di Troia, Quagliano, Bombino bianco, Bombino nero, Impigno, Microsatellites, Kinship

\section{Background}

Vitis vinifera is one of the earliest domesticated crop and it is native of the Mediterranean and Middle East areas. Dioecy and allogamy are found in all wild Vitis vinifera L. subsp. sylvestris and for a successful reproduction, crosspollination is required while inbreeding leads to severe

\footnotetext{
*Correspondence: carlo.bergamini@crea.gov.it;

donato.antonacci@crea.gov.it

${ }^{+}$C. Bergamini and R. Perniola contributed equally to this work

${ }^{\ddagger}$ A. R. Caputo and D. Antonacci contributed equally as team coordinators

${ }^{1}$ Consiglio per la ricerca in agricoltura e l'analisi dell'economia agraria-

CREA - Unità di ricerca per l'uva da tavola e la vitivinicoltura in ambiente mediterraneo, Research Unit for Viticulture and Enology in Southern Italy, Via Casamassima, 148, 70010 Turi, BA, Italy

Full list of author information is available at the end of the article
}

genetic depression of progeny. However, in the cultivated species (subspecies sativa) hermafroditism and selfpollination were selected during the domestication process to improve berry production. The issues that would arise from this contrast are avoided thanks to the process of vegetative propagation, a procedure that allows to fix favorable genes combinations in selected genotypes, making them virtually immortal and escape the need for sexual reproduction. Consequently, some varieties might be very ancient: Pinot noir, Muscat Blanc à Petits Grains, and Sultanina, for example, date back probably to one or two thousands of years ago (Bowers et al. 1999a; This et al. 2006). Moreover, the population structure of Vitis vinifera generated recently a considerable 
research interest but it is still debated, mostly because it is not clear how accurately germplasm collection used in these studies represent the real population of this species (Myles et al. 2011; Emanuelli et al. 2013; Bacilieri et al. 2013). Indeed, some researchers believe that few varieties are actually progenitors of most of the relevant cultivated genotypes and such elite cultivars are responsible for the complex and close relationships between the cultivars. (Myles et al. 2011).

Vitis vinifera growing practice was spread following historic migrations of people and progression of civilization; the same flow might be assumed for cultivated varieties. Many grape varieties have no clear origins, not only for the nineteenth century outbreaks of American diseases that lead to an extinction of many ancient varieties and heavy reduction of diversity, but also because of the shuffling and exchanges of cuttings that occurred over the centuries following trades and migrations, resulting in a masking of the true origins of autochthonous cultivated varieties (McGovern 2004). Likewise, synonymy and homonymy occurrence in grapevine varieties makes origin assessment and pedigree reconstruction even more difficult. In this context, molecular markers could be used to solve these challenges; in particular, fingerprints of microsatellites, also called Simple Sequence Repeats (SSR), can unequivocally identify varieties despite changes of plant phenotype in different environmental conditions and severe changes in morphology due to virus infection and lack of vigour. Likewise, an additional ideal use of SSR fingerprinting is to investigate genetic relations and identify pedigrees, because of the co-dominant, neutral behavior and Mendelian segregation of these markers (Dakin and Avise 2004).

Although SSR fingerprinting has been used by many researchers to investigate the Italian grapevine biodiversity, one of the greatest considering its strategic position in the middle of the Mediterranean Sea, results so far have been challenging to be interpreted (Sefc et al. 2000). The most important autochthonous cultivated varieties appear uncorrelated. As an example, the origins of the renowned variety $U v a$ di Troia are still at the mythological tale state, being believed to date back to the arrive in Daunia (Apulia region) of the hero Diomedes, who carried cuttings of grapevines from the Anatolian city of Troy after its destruction, as described by Homer in the Iliad.

In this paper we present a study that started from the characterization of the South Italian grapevine biodiversity by means of 54 nuclear and 5 chloroplast microsatellites, then proceeded to analyze possible parental relationship. This analysis gave surprising results: a whole new family of renowned grapevine varieties, composed by two parents and three siblings. In order to investigate the genealogy of Uva di Troia, South Italian grapevine biodiversity has been used with more than 2000 accessions previously screened for genetic relatedness by 13 SSRs (Bergamini et al. 2013). In this study 107 grapevine cultivars best representing South Italian grapevine biodiversity have been genotyped by 54 nuclear and 5 chloroplast microsatellites in order to look for genetic relatedness among them. Also, the study included detailed analysis of similarity in ampelographic characteristics and search of historical backgrounds in case of established kinships.

\section{Methods}

\section{Plant material}

The germplasm collection of CREA-UTV in Turi (Bari, Italy) (Lat. $40^{\circ} 92 \quad 57^{\prime} 24.54^{\prime \prime} \mathrm{N}$, Lon. $17^{\circ} \quad 00^{\prime} 28.94^{\prime \prime} \mathrm{E}$ ) includes internationally spread varieties of both table and wine grapes and consist of about a thousand of unique genotypes. The collection includes autochthonous varieties of the Southern Italian regions (Basilicata, Calabria, Campania, Apulia and Sicily). A sup-population, consisting of 107 most diffused and cultivated varieties, have been selected as best representing South-Italian grapevine biodiversity and further characterized in this study.

\section{DNA extraction and molecular characterization}

DNA fingerprinting was performed as described in Bergamini et al. (2013). Briefly, genomic DNA was extracted from young leaf tissue using Qiagen DNeasy Plant Mini Kit (Qiagen, Valencia, CA) on liquid nitrogen-frozen leaf samples, after homogenization by Qiagen Tissue Lyser (Qiagen, Valencia, CA), according to the manufacturer instruction protocol. Purified DNA was used as template in a PCR amplification for genotyping using 60 nuclear SSR loci ISV2, ISV3, ISV4, VVS2 (Thomas and Scott 1993), VVMD5, VVMD7, VVMD25, VVMD27, VVMD28, VVMD32 (Bowers et al. 1996, 1999b) VrZAG62, VrZAG79, VrZAG21, VrZAG112 (Sefc et al. 1999) and VMCNG4b9 (Vitis Microsatellite Consortium), VChr-1b, -2b, -3a, -4a, $-5 \mathrm{~b},-5 \mathrm{c},-6 \mathrm{a},-7 \mathrm{~b},-8 \mathrm{~b},-9 \mathrm{a}$, $-10 \mathrm{~b},-11 \mathrm{~b},-12 \mathrm{a},-13 \mathrm{a},-15 \mathrm{a},-16 \mathrm{a},-17 \mathrm{a},-18 \mathrm{a},-19 \mathrm{a}$ (Cipriani et al. 2008) and VVI-b01, -b23, -b63, -b66, -b94, -f52, -h54, -i51, -m10, - $\mathrm{m} 11,-\mathrm{m} 25,-\mathrm{n} 54,-\mathrm{n} 61,-\mathrm{n} 94$, -o55, -p25b, -p37, -p77, -r09, -s21, -s58, -s63, -u04, -v37, -v61, -v69 (Merdinoglu et al. 2005). A set of chloroplast specific microsatellite loci primers was also employed: ccSSR-5, ccSSR-14, ccSSR-23 (Chung and Staub 2003), cPSSR10 (Weising and Gardner 1999), NTCP8 (Bryan et al. 1999). Chlorotypes definitions are defined following Arroyo-Garcia et al. (2006). The cycling profiles were as reported in Bergamini et al. (2013). PCR reactions were conducted in $10 \mu \mathrm{l}$ volume containing $25 \mathrm{ng}$ of genomic DNA, 5 pmol of each forward and reverse primer and 
$5 \mu \mathrm{l}$ of QIAGEN Fast Cycling PCR Master Mix 2X. Three or more primer pairs were carefully combined to co-amplify in a single reaction and each forward primer was labeled with WellRED dyes, D2-PA (black), D3-PA (green) or D4-PA (blue), at the $5^{\prime}$ end. Amplicons were analysed on a $\mathrm{CEQ}^{\mathrm{TM}} 8000$ Series Genetic Analysis System, automatically sized using a CEQ DNA Size Standard Kit 400 (Beckman Coulter S.p.A., Milan, Italy), and then visually inspected and manually recorded.

\section{Data analysis}

Amplicons size were rounded, according to the length of the core repeat of each analysed SSR, with an Excel (Microsoft, Redmond, WA) computational sheet. For each considered locus Number of alleles, Expected Heterozygosity, Observed Heterozygosity and Estimated Frequency of Null Alleles were calculated with the aid of the software Identity version 1.0 (Wagner and Sefc 1999) and already reported in Bergamini et al. (2013). Similarly, the same software was used to calculate cumulative Likelihood ratio (LRs) statistics for the detected, putative parent-offspring groups.

\section{Ampelographic and Ampelometric characterizations}

Morphology was recorded in three consecutive years (2009-2011) by means of primary and secondary descriptors, as indicated in the frame of the 2nd edition of the Organisation Internationale de la Vigne et du Vin (OIV) Descriptor List for grape varieties and Vitis species (available: http://www.oiv.int/oiv/files/5\%20-\%20 Publications/5\%20-\%201\%20Publications\%20OIV/EN/51-9_Liste_descripteurs_2ed_EN.pdf). Ampelometric characterization was performed on 20 leaves sampled at the eighth node for each analyzed variety with the aid of the software SuperAmpelo 2.0 (Comunita'Monastica SS. Pietro e Paolo, Germagno VB, Italy) (Soldavini et al. 2009).

\section{Results and discussion Molecular analysis}

South Italian countryside have been explored in the past years to find and recover ancient autochthonous varieties. All recovered accessions were genotyped at 13 microsatellites allowing the unequivocal identification of each analyzed one. The genetic characteristics of our germplasm collection have already been described in a previous paper (Bergamini et al. 2013).

Some peculiar varieties have been characterized at a higher number of microsatellites (Bergamini et al. 2013) to ascertain parental relationships. Overall 107 varieties were evaluated at 54 nuclear microsatellites. Additionally, five plastid microsatellites, commonly used for chloroplast haplotype assaying, were screened. They are used to assign the sex of the two parents in a cross, considering the maternal inheritance of plastid genomes in the Vitis genus (Arroyo-García et al. 2006).

The present study revealed a new family composed of two parents and three siblings. The parents were Bombino bianco and Uva rosa antica, a previously unknown variety found near Ricigliano, in the Montain townships "Tanagro- Alto e Medio Sele", province of Salerno. The three siblings were: the renowned $U v a d i$ Troia, the Bombino nero and the Impigno (Fig. 1). Values of all 54 nuclear and 5 chloroplast microsatellites are reported in Table 1. As a confirmation, 6 more nuclear microsatellites were additionally analyzed, but only in the five members of the new discovered family, and their values are reported at the bottom of Table 1. Only one of the 60 microsatellites used in this study showed discrepant values for the proposed kinship. VChr-17a was in homozygosis at $189 \mathrm{pb}$ in Bombino bianco, and at 179 $\mathrm{pb}$ in Uva rosa antica: only Impigno had heterozygosis $179 / 189 \mathrm{pb}$ at this locus, while Uva di Troia and Bombino nero had not the $179 \mathrm{pb}$ allele as expected. As already showed (Bergamini et al. 2013; Gasparro et al. 2013) the VChr-17a microsatellite is strongly affected by null alleles as denoted by the much lower observed heterozygosity frequency (0.308411) compared to the expected heterozygosity frequency (0.501834): the estimated frequency of null alleles is as high as 0.12879 and therefore the Uva rosa antica very likely has a null allele and this allele was inherited by Uva di Troia and Bombino nero.

Combined likelihood ratios (LR) for the proposed cross, calculated considering allelic frequencies over 50 loci, are reported in Table 2: LR's for the proposed cross are $2.90 \times 10^{36}, 1.69 \times 10^{41}, 7.87 \times 10^{30}$, and the LR including $95 \%$ upper confidence limits of observed allele frequencies calculated over all loci are respectively $2.92 \times 10^{25}, 2.32 \times 10^{29}, 1.36 \times 10^{21}$ (respectively for Uva di Troia, Bombino nero and Impigno; values calculated on 107 varieties at 50 loci). Even in the most stringent conditions the Bombino bianco and Uva rosa antica were ranging from $8.63 \times 10^{4}$ to $2.63 \times 10^{6}$ times more probable with $95 \%$ upper confidence than a close relative of one of the two proposed parents was the real parent limit (see values in Table 2 labeled as "rel(2) $\times(1)$ " and “(2) $\times \operatorname{rel}(1)$ ").

Literature search showed that Impigno, the less notable of the three siblings, have been previously allocated in a possible kinship: noteworthy, his putative parents were Bombino bianco, the same as in our study, and Quagliano, a variety cultivated only in some alpine valleys in the north-west of Italy (Cipriani et al. 2010). This coincidence strongly suggested a synonymy between the south Italian Uva rosa antica and the north Italian Quagliano. To confirm this possibility we compared 


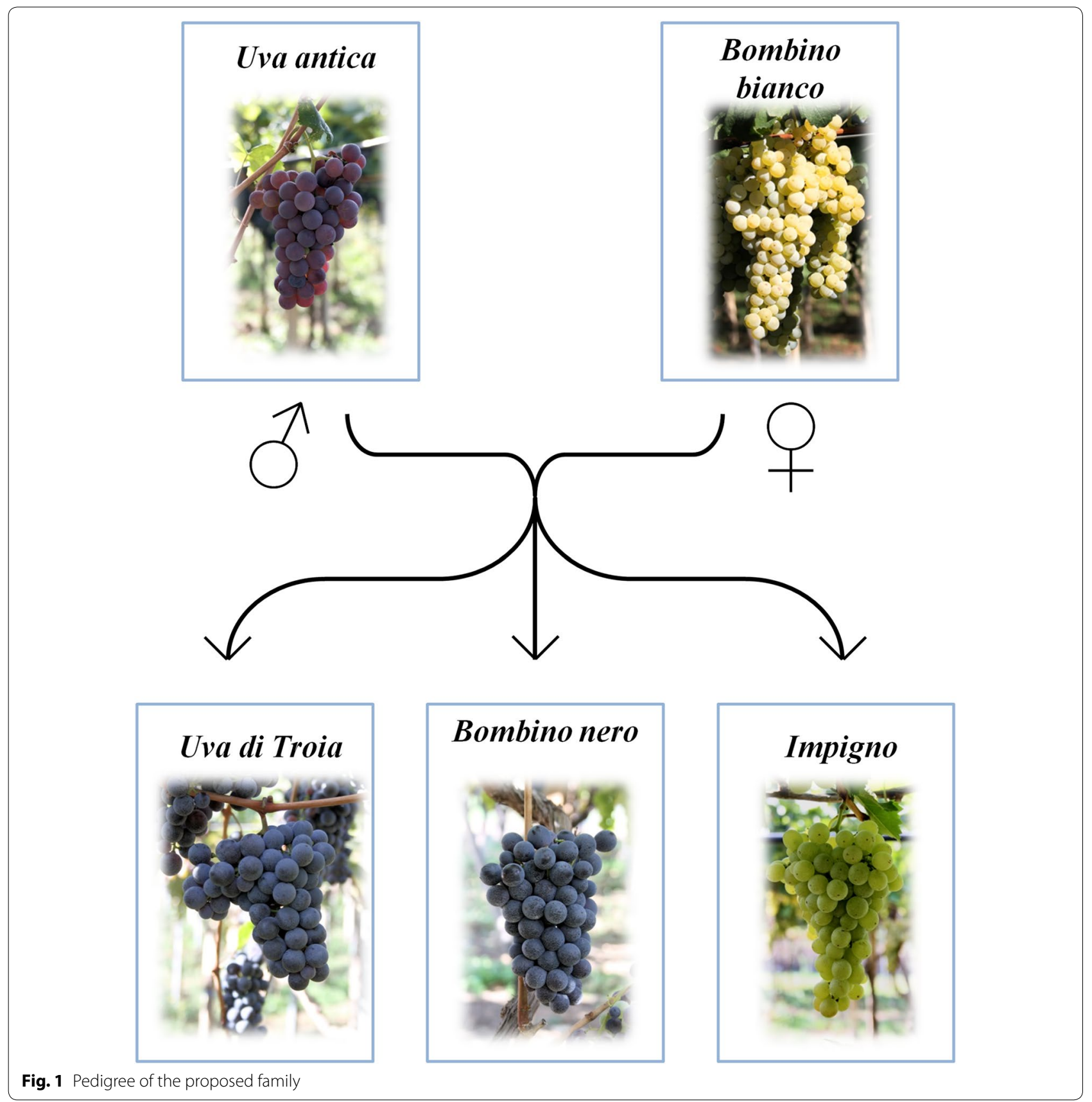

SSR profiles of Quagliano published in the European Vitis Database (available: http://www.eu-vitis.de/index. php) with those we have scored for Uva rosa antica, and found identity at all analyzed loci: considering the allelic frequencies of the nine loci used in the European Vitis Database (VVS2, MD5, MD7, MD27, ZAG62, ZAG79, MD25, MD28 and MD32) the combined Probability of Identity $(\mathrm{PI})$ is $6.95438 \times 10^{10}$. Despite the other two siblings, Uva di Troia and Bombino nero, were included in the analysis of Cipriani et al. (Cipriani et al. 2010), they passed unnoticed because of the high frequency of null alleles occurrence in long-core repeat microsatellites used in that study, one of which likely being VChr-17a. Another earlier study (Zulini et al. 2002) had characterized Bombino bianco and Bombino nero at six common microsatellites and the two varieties resulted unrelated because of incompatible alleles at the ZAG62 locus but there is an evident mistake in the size call and rounding of values in the Bombino nero genotype which were the only ones in the whole list of varieties shifted by just one 
Table 1 Molecular data: The genotype of 60 SSR loci and five chloroplast SSR loci of the analyzed varieties for the proposed kinship and of Pinot Noir as reference for size calibration

\begin{tabular}{|c|c|c|c|c|c|c|}
\hline SSR loci & Uva rosa antica Quagliano & Bombino bianco & Uva di Troia & Bombino nero & Impigno & Pinot Noir \\
\hline VVS2 & $133-143$ & $145-151$ & $143-151$ & $133-145$ & $133-145$ & $137-151$ \\
\hline VVMD5 & $225-225$ & $227-231$ & $225-231$ & $225-227$ & $225-227$ & $227-237$ \\
\hline VVMD7 & $238-242$ & $248-252$ & $242-252$ & $238-252$ & $238-248$ & $238-242$ \\
\hline VVMD25 & $239-267$ & $241-263$ & $263-267$ & $239-241$ & $239-241$ & $239-249$ \\
\hline VVMD27 & 178-188 & 180-194 & 188-194 & $178-180$ & 178-194 & $184-188$ \\
\hline WMD28 & $249-259$ & $245-249$ & $245-249$ & $249-249$ & 249-249 & $219-237$ \\
\hline WMD32 & $240-250$ & $258-272$ & $250-272$ & $240-258$ & $250-272$ & $240-272$ \\
\hline VrZAG21 & $191-205$ & $191-191$ & $191-191$ & $191-205$ & $191-191$ & $201-207$ \\
\hline VrZAG62 & $185-187$ & 189-199 & 187-199 & 185-199 & $185-189$ & 187-193 \\
\hline VrZAG79 & $250-254$ & $250-258$ & $250-250$ & $254-258$ & $254-258$ & $240-244$ \\
\hline ISV2 & $166-170$ & $166-170$ & $170-170$ & $166-166$ & $166-170$ & $152-166$ \\
\hline ISV3 & $134-140$ & $140-146$ & $140-140$ & $140-140$ & $140-140$ & $134-146$ \\
\hline ISV4 & 189-199 & 189-193 & 189-199 & 189-189 & 189-189 & $171-179$ \\
\hline VMCNG4b9 & $162-164$ & $150-176$ & $164-176$ & $162-176$ & $162-176$ & $158-162$ \\
\hline VChr-1b & $96-108$ & $100-100$ & $96-100$ & $96-100$ & 100-108 & $100-108$ \\
\hline VChr-2b & $116-124$ & $116-124$ & $116-124$ & $116-124$ & $116-124$ & $124-124$ \\
\hline VChr-4a & 182-199 & 182-199 & 199-199 & 182-182 & 182-199 & 182-199 \\
\hline VChr-5b & $202-218$ & $202-206$ & $206-218$ & $202-202$ & $202-202$ & 190-190 \\
\hline VChr-5c & $104-128$ & $88-120$ & $88-128$ & $104-120$ & 88-104 & $96-116$ \\
\hline VChr-6a & $182-186$ & $182-182$ & $182-182$ & $182-186$ & $182-186$ & $182-186$ \\
\hline VChr-7b & $181-185$ & $181-189$ & $181-185$ & $181-186$ & $181-189$ & $181-189$ \\
\hline VChr-9a & $90-118$ & 109-115 & $90-115$ & $90-115$ & $115-118$ & $90-98$ \\
\hline VChr-10b & 134-134 & 138-144 & 134-138 & $134-144$ & $134-144$ & 138-144 \\
\hline VChr-11b & $155-160$ & $157-164$ & $160-164$ & 155-157 & $155-164$ & $152-164$ \\
\hline VChr-12a & $137-144$ & $144-144$ & $144-144$ & $144-144$ & $144-144$ & $137-144$ \\
\hline VChr-13a & $141-157$ & 149-157 & $157-157$ & $141-149$ & 149-157 & $157-157$ \\
\hline VChr-15a & $157-157$ & 149-149 & 149-157 & 149-157 & 149-157 & $153-157$ \\
\hline VChr-16a & $110-114$ & $114-114$ & $110-114$ & $110-114$ & $110-114$ & $102-164$ \\
\hline VChr-17a & $181-/ /$ & 189-189 & 189-// & 189-// & $181-189$ & 189-189 \\
\hline VChr-18a & $164-168$ & $152-160$ & $160-168$ & $152-164$ & $152-168$ & 164-168 \\
\hline VChr-19a & $141-141$ & $138-141$ & $141-141$ & $138-141$ & $138-141$ & $123-138$ \\
\hline VVI-b01 & 298-298 & 294-298 & 294-298 & 294-298 & $294-298$ & $292-298$ \\
\hline VVI-b63 & 150-154 & $126-154$ & $126-154$ & $126-154$ & $150-154$ & $148-148$ \\
\hline VVI-b94 & $292-306$ & $284-292$ & $292-306$ & $292-306$ & 284-306 & $284-296$ \\
\hline VVl-f52 & $262-274$ & $260-260$ & $260-262$ & $260-274$ & $260-262$ & $284-286$ \\
\hline VVI-h54 & $166-168$ & $166-174$ & $166-166$ & $166-174$ & $166-166$ & $164-168$ \\
\hline VVI-i51 & $253-265$ & $263-263$ & $253-263$ & $263-265$ & $263-265$ & $265-267$ \\
\hline VVI-m10 & $357-371$ & $369-379$ & $371-379$ & $357-379$ & $357-369$ & $357-371$ \\
\hline VVI-m11 & 291-301 & 287-301 & 287-291 & $301-301$ & 291-301 & $291-291$ \\
\hline VVI-m25 & $167-169$ & $177-177$ & $171-177$ & 169-177 & $167-177$ & $167-187$ \\
\hline VVI-n54 & $100-106$ & $106-112$ & $106-112$ & $106-106$ & $106-106$ & $92-96$ \\
\hline VVI-n61 & $361-375$ & $349-371$ & $349-361$ & $361-371$ & $349-375$ & $371-377$ \\
\hline VVI-n94 & 278-289 & $286-289$ & 278-289 & $286-289$ & 289-289 & 289-289 \\
\hline VVI-055 & $141-143$ & $143-147$ & $141-147$ & $141-147$ & $141-147$ & $143-147$ \\
\hline VVI-p25b & $342-360$ & $340-362$ & $360-362$ & $340-342$ & $360-362$ & $362-362$ \\
\hline VVI-p37 & 150-156 & $144-148$ & 144-150 & $148-156$ & $144-150$ & $140-150$ \\
\hline VII-p77 & $172-182$ & 186-190 & 172-190 & 182-186 & 172-190 & 180-190 \\
\hline VVI-r09 & $258-260$ & $258-264$ & $258-264$ & $258-260$ & $258-258$ & $242-248$ \\
\hline
\end{tabular}


Table 1 continued

\begin{tabular}{|c|c|c|c|c|c|c|}
\hline SSR loci & Uva rosa antica Quagliano & Bombino bianco & Uva di Troia & Bombino nero & Impigno & Pinot Noir \\
\hline$\overline{\mathrm{VVI}-\mathrm{s} 21}$ & $284-284$ & $284-290$ & $284-284$ & $284-290$ & $284-284$ & $270-284$ \\
\hline VVI-s58 & $304-308$ & $304-308$ & $308-308$ & $304-308$ & $304-304$ & 294-294 \\
\hline VVI-s63 & $190-212$ & 190-212 & 190-212 & 190-190 & 190-212 & 190-190 \\
\hline VI-u04 & $182-189$ & 182-191 & 182-191 & 182-191 & $182-189$ & $166-170$ \\
\hline VIl-v37 & $159-167$ & $159-167$ & 159-167 & $159-167$ & $167-167$ & 149-159 \\
\hline VVI-v69 & $271-271$ & $257-271$ & $257-271$ & $257-271$ & $257-271$ & 289-291 \\
\hline cCSSR-5 & 256 & 255 & 255 & 255 & 255 & 256 \\
\hline ccSSR-14 & 201 & 202 & 202 & 202 & 202 & 201 \\
\hline ccSSR-23 & 285 & 286 & 286 & 286 & 286 & 285 \\
\hline cpSSR10 & 110 & 111 & 111 & 111 & 111 & 110 \\
\hline NTCP8 & 250 & 250 & 250 & 250 & 250 & 250 \\
\hline VChr-3a & 190-190 & 187-199 & 190-199 & 187-190 & 187-190 & 202-202 \\
\hline VChr-8b & $121-136$ & 103-106 & $106-121$ & 103-136 & 103-136 & 103-139 \\
\hline VrZAG112 & $231-235$ & $237-245$ & $231-237$ & $231-237$ & $231-237$ & $243-245$ \\
\hline VI-b23 & $305-323$ & $305-311$ & $305-305$ & $305-305$ & $305-305$ & $309-331$ \\
\hline WI-b66 & 89-89 & 89-109 & 89-109 & 89-109 & 89-109 & 103-109 \\
\hline WVI-v61 & 169-190 & 169-192 & 169-190 & 169-192 & 169-190 & $169-169$ \\
\hline
\end{tabular}

The last six loci were analyzed only in the five members of the proposed family. Allele lengths are in bp. ND: not detected

\section{Table 2 Likelihood ratios: (LRs) for the proposed parentage}

Uva di Troia = Bombino bianco (1) $\times$ Uva rosa antica/Quagliano (2)

Combined over all 50 loci in 107 cultivars

Likelihood ratios including calculated allele frequencies

Likelihood ratios including 95 \% upper confidence limits of observed allele frequencies

Bombino nero $=$ Bombino bianco $(1) \times$ Uva rosa antica/Quagliano (2)

Combined over all 50 loci in 107 cultivars

Likelihood ratios including calculated allele frequencies

Likelihood ratios including 95 \% upper confidence limits of observed allele frequencies

Impigno = Bombino bianco $(1) \times$ Uva rosa antica/Quagliano (2)

Combined over all 50 loci in 107 cultivars

Likelihood ratios including calculated allele frequencies

$$
\begin{array}{lllll}
X \times Y & X \times(1) & \operatorname{rel}(2) \times(1) & (2) \times X & (2) \times \operatorname{rel}(1) \\
2.90 \times 10^{36} & 4.49 \times 10^{25} & 5.13 \times 10^{07} & 4.86 \times 10^{18} & 1.74 \times 10^{06} \\
2.92 \times 10^{25} & 2.42 \times 10^{19} & 2.50 \times 10^{06} & 1.04 \times 10^{14} & 8.63 \times 10^{04}
\end{array}
$$

Likelihood ratios including $95 \%$ upper confidence limits of observed allele frequen-

cies

Likelihood ratios provided in this table are combined over 50 loci

$\mathrm{X} \times \mathrm{Y}$ is the ratio of probability that the proposed parents gave rise to the offspring's genotype versus the probability that two random individuals give rise to the offspring's genotype. (Proposed parents) versus (two random cultivars)

$X \times(1)$ is the Likelihood ratio for: (Proposed parents) versus (random individual $\times$ proposed parent 1 )

rel $(2) \times(1)=$ (Proposed parents) versus (close relative of proposed parent $2 \times$ proposed parent 1$)$

(2) $\times X=$ (Proposed parents) versus (Proposed parent $2 \times$ random cultivar)

(2) $\times \operatorname{rel}(1)=($ Proposed parents) versus (Proposed parent $2 \times$ close relative of proposed parent 1 )

unit. Recently, a large genotyping study first hypothesize the putative kinship of Uva di Troia, albeit using only 20 SSR (Lacombe et al. 2013). Notably, the authors reported that Quagliano is not only a synonym of Uva rosa antica, but also of Bouteillan noir, an old variety cultivated in the Provence region, in the southern France.
Chloroplast microsatellite analysis of the five varieties under study for this family showed two different haplotype for the two parents: type "D" for Bombino bianco and type "A" for Uva rosa antica/Quagliano, respectively. All three siblings showed the type "D" chloroplast haplotype, thus Bombino bianco was the seed-bearer (female 
parent) and Uva rosa antica/Quagliano was the pollen donor (male parent) for all three of them.

\section{Ampelographic and ampelometric description}

As a reference for other researchers, we report in Table 3 a detailed ampelographic description of the five varieties under study. From the entire ampelographic and ampelometric data set it was possible to perform an analysis of similarity between each parent and its offspring: the software SuperAmpelo (as described in the user manual (http://www.pomologia.it/SuperAmpelo/Documenti. aspx) calculated that the Bombino nero has the highest similarity index (63\%) with the parent Uva rosa antica/ Quagliano while the Impigno and Uva di Troia show, respectively, a similarity of 70 and $65 \%$ with the parent Bombino Bianco (Fig. 2). No other significant morphological similarity were observed between the parents nor the offspring. In spite of very demanding analyzes and generating massive ampelographic and ampelometric data set (in contrary to microsatellites), it was not sufficient to help or contribute revealing of proposed kinship.

\section{Relevant notes on varieties under study}

The Quagliano is a minor variety, known as being cultivated only in the Piedmont region, north-west of Italy (Fig. 3), exclusively in the Stura, Grand, Maira and Vardita valleys and, until now, its presence was never been reported in other areas of Italy. Its cultivation in those valleys is first documented in an act published in 1739: "Bandi campestri della città di Busca compreso il tenimento detto di Castelreale spettante alla medesima comunità e specialmente li boschi selvatici" (Tenders of Busca rural town including the containment said Castelreale entitled to the same community and especially the wild woods). Slightly earlier, in 1715 , is the first documented citation of the Bouteillan noir, synonym of Quagliano on the other side of the Alps, in the Vaucluse, southern France (Robinson et al. 2013).

The Bombino bianco is a variety cultivated in large part of Italy (Fig. 3), having over 70 different known synonymies according to VIVC database, the Vitis International Variety Catalogue (available at www.vivc.de). Its diffusion is probably due to its great productivity, vigor and suitability to different forms of training with high yields per hectare. Its first documented citation dates back to 1825 in Acerbi's work "delle viti italiane" (Acerbi 1825).

The Uva di Troia is a variety exclusively cultivated in the south of Italy, especially in the Apulia region and in some part of Campania region (Fig. 3). There are 15 different synonyms reported in the VIVC database for this variety. Uva di Troia gives wines that each new vintage are gaining considerable interests, filling the gap of Apulian winemaking, historically devoted to must production. Uva di Troia legendary origins and its fascinating name, recalling the ancient poems of Homer, have frequently raised researcher interest. Costacurta and De Gennaro (Costacurta and Germinario 2010), summarizing other studies, set the birth of Uva di Troia name in 1875 at the hands of Giovanni Frojo. Before that time it was known only with its synonym Vitigno di Canosa (Bruni 1844). Supposedly, the first indirect citation of Uva di Troia dates back to 1791 when the canon Gaetano De Lucretiis reported of a new vines that was spreading in the north Apulian area: he called that variety Somarello, a synonym of Uva di Troia still in use today in that area (De Lucretiis 1791).

The Bombino nero is a variety mostly cultivated in the south of Italy (Fig. 3), there are 5 known synonyms in the VIVC database and, like most of the Apulia varieties, there are no known citation of it preceding the ampelographic descriptions of Di Rovasenda (1877).

The Impigno is the last of the three siblings, a minor variety cultivated only in one province of the Apulia region (Fig. 3) and first cited only in 1905 (Del Gaudio and Giusto 1965).

\section{Historical perspective}

Recurrence of families in Vitis vinifera L. varieties is not a new feature, indeed it is well known that at least 23 varieties of the northeast of France, some of them are spread internationally by now, are all progeny from repeated crosses starting from early middle age of Pinot noir and Gouais blanc (Bowers et al. 1999a; Lacombe et al. 2013). Whether the new South Italian family of varieties originated from spontaneous crossing or there were intentionality created, remain a matter of speculation. Althoug science was highly developed in antiquity, the first reported experiments addressing the sexual reproduction in higher plants and assigned the male role to pollen, dates back to the late seventeenth century carried out by the German botanist R.J. Camerarius and brought to an outbreak of experiments in the following centuries up to the celebrated crossings of the Father of Genetics, the Czech monk Gregor Mendel.

In the family we discovered the egg donor parent and the pollen donor one, Bombino bianco and Uva rosa antica/Quagliano respectively, remain the same for each cultivar of progeny, thus this family could have been originated in a single place and possibly in a single time. A valid hypothesis would also be the common cultivation of these cultivars over long period of time and crossings happened in different places and different time: both cultivars could have been used to be sort of "leading varieties together cultivated" in many vineyard, therefore increasing the chances of repeating the same combination of parents. 
Table 3 Ampelographic characters: in Uva rosa antica/Quagliano, Bombino bianco, Uva di Troia, Bombino nero and Impigno

\begin{tabular}{|c|c|c|c|c|c|}
\hline Caracter code and description & Uva rosa antica/Quagliano & Bombino bianco & Uva di Troia & Bombino nero & Impigno \\
\hline 001 Young shoot: opening of the shoot tip & 5 & 5 & 5 & 5 & 5 \\
\hline $\begin{array}{l}003 \text { Young shoot: intensity of anthocyanin coloration on } \\
\text { prostrate hairs of the shoot tip }\end{array}$ & 3 & 7 & 1 & 5 & 1 \\
\hline 004 Young shoot: density of prostrate hairs on the shoot tip & 1 & 5 & 1 & 5 & 5 \\
\hline 006 Shoot: attitude (before tying) & 3 & 3 & 3 & 1 & 7 \\
\hline 007 Shoot: color of the dorsal side of internodes & 3 & 2 & 3 & 3 & 2 \\
\hline 008 Shoot: color of the ventral side of internodes & 2 & 2 & 2 & 2 & 3 \\
\hline 016 Shoot: number of consecutive tendrils & 1 & 1 & 1 & 1 & 1 \\
\hline 051 Young leaf: color of upper side of blade (4th leaf) & 1 & 3 & 1 & 1 & 1 \\
\hline $\begin{array}{l}053 \text { Young leaf: density of prostrate hairs between main } \\
\text { veins on lower side of blade (4th leaf) }\end{array}$ & 1 & 5 & 3 & 7 & 1 \\
\hline 067 Mature leaf: shape of blade & 3 & 3 & 2 & 2 & 3 \\
\hline 068 Mature leaf: number of lobes & 3 & 3 & 3 & 2 & 3 \\
\hline $\begin{array}{l}070 \text { Mature leaf: area of anthocyanin coloration of main } \\
\text { veins on upper side of blade }\end{array}$ & 1 & 3 & 3 & 1 & 3 \\
\hline 072 Mature leaf: goffering of blade & 1 & 1 & 1 & 1 & 5 \\
\hline 074 Mature leaf: profile of blade in cross section & 2 & 1 & 2 & 1 & 1 \\
\hline 075 Mature leaf: blistering of upper side of blade & 1 & 1 & 1 & 5 & 1 \\
\hline 076 Mature leaf: shape of teeth & 4 & 3 & 4 & 5 & 5 \\
\hline $\begin{array}{l}079 \text { Mature leaf: degree of opening/overlapping of petiole } \\
\text { sinus }\end{array}$ & 5 & 5 & 7 & 7 & 7 \\
\hline 080 Mature leaf: shape of base of petiole sinus & 2 & 1 & 1 & 2 & 1 \\
\hline 081-1 Mature leaf: teeth in the petiole sinus & 1 & 9 & 1 & 1 & 1 \\
\hline 081-2 Mature leaf: petiole sinus base limited by vein & 1 & 1 & 1 & 1 & 1 \\
\hline 083-2 Mature leaf: teeth in the upper lateral sinuses & 1 & 9 & 1 & 1 & 1 \\
\hline $\begin{array}{l}084 \text { Mature leaf: density of prostrate hairs between main } \\
\text { veins on lower side of blade }\end{array}$ & 1 & 5 & 5 & 7 & 3 \\
\hline $\begin{array}{l}087 \text { Mature leaf: density of erect hairs on main veins on } \\
\text { lower side of blade }\end{array}$ & 7 & 5 & 7 & 1 & 3 \\
\hline 094 Mature leaf: depth of upper lateral sinuses & 5 & 5 & 5 & 5 & 5 \\
\hline 202 Bunch: length (peduncle excluded) & 5 & 7 & 3 & 3 & 5 \\
\hline 204 Bunch: density & 7 & 3 & 3 & 3 & 7 \\
\hline 206 Bunch: length of peduncle of primary bunch & 5 & 3 & 1 & 3 & 3 \\
\hline 208 Bunch: shape & 1 & 3 & 1 & 1 & 1 \\
\hline 209 Bunch: number of wings of the primary bunch & 2 & 3 & 2 & 2 & 2 \\
\hline 220 Berry: length & 5 & 5 & 5 & 5 & 5 \\
\hline 221 Berry: width & 5 & 5 & 5 & 5 & 4 \\
\hline 223 Berry: shape & 2 & 2 & 3 & 2 & 3 \\
\hline 225 Berry: color of skin & 5 & 1 & 6 & 6 & 1 \\
\hline 231 Berry: intensity of flesh anthocyanin coloration & 1 & 1 & 1 & 1 & 1 \\
\hline
\end{tabular}

Values are referred to the 'Descriptor List for grape varieties and Vitis species' of the Organisation Internationale de la Vigne et du Vin

Regarding the Uva rosa antica/Quagliano, as already mentioned, it was considered a north Italian variety native of the Piedmont valleys, considering the records of its cultivation dating the beginning of the eighteenth century, and only recently shown that it was also contemporary cultivated on the other side of the alps with the synonym Bouteillan noir. It is told that the Quagliano was used by the Romans to produce wines of the type called aigleucos, kept sweet by restraining the fermentation with frequent decanting and immersion of the amphorae into wells (Pliny the Elder, in year 77 AD Historia Naturalia XIV, 11). In the south of Italy the Uva rosa antica, synonym of the northern Quagliano and Bouteillan noir, has been cultivated most likely from the late 

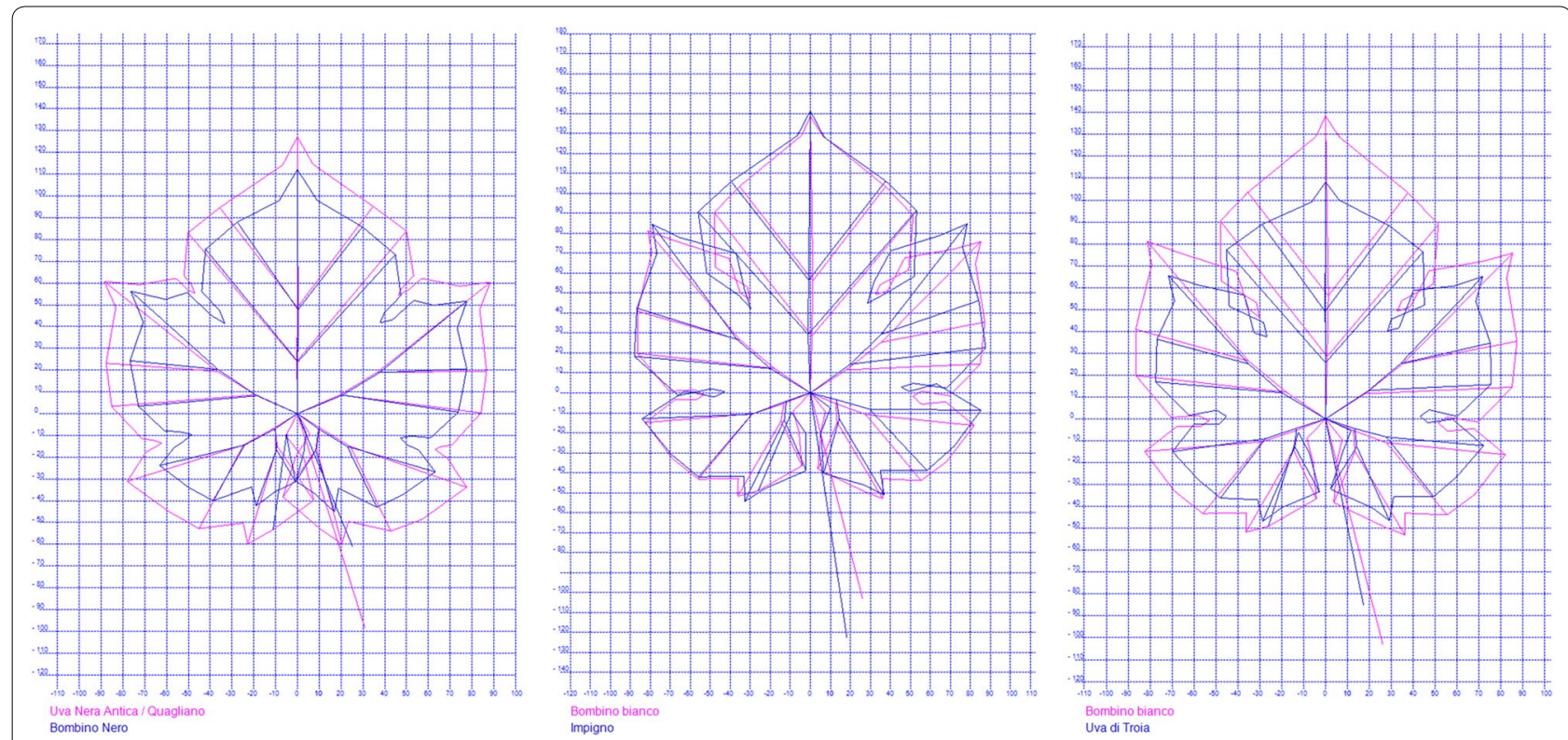

Fig. 2 Leaves ampelometric comparison. Ampelometric comparison with the highest Similarity Index between the mean profiles of parental and offspring leaves (respectively Uva rosa antica/Quagliano vs Bombino nero, Bombino bianco vs Uva di Troia and Bombino bianco vs Impigno)

eighteenth century. In this part of the Italian peninsula documentation is missing regarding cultivated varieties prior to the mid-nineteenth century. Instead, microsatellite analysis revealed its founding role as parent of $U v a d i$ Troia, Bombino nero and Impigno. For this purpose it is important to point out that the creation, the evaluation and the spreading of a new variety is a very slow process, taking nowadays more than 30 years: three centuries ago, in an age preceding the New Word pest crisis occurred during the second half of the $1800 \mathrm{~s}$, this procedure could have taken far more than half a century. Furthermore, it could be speculated a role for the prior crisis in the year 1709, this time regarding the climate, the Great Frost or Grand Hiver, the coldest winter of the past 500 years, the most extreme event of the so-called Little Ice Age in the sixteenth to nineteenth centuries (Luterbacher et al. 2004). It caused the loss of many vineyards in northern and central Europe and it could have led to the need of reintroducing varieties spared from the extremely low temperatures in southern areas. This agrees to the $U v a$ rosa antica/Quagliano being a late ripening cultivar (Molon 1906), a feature commonly found in varieties cultivated in warmer climates and southern latitudes.

Lastly, in 1877 it was reported by Di Rovasenda in Barletta, south of Italy, the cultivar Quagliara, a very similar denomination to Quagliano, and if it was the same variety, it could have been its last and only report before being lost (Di Rovasenda 1877).

By combining molecular data and historical documentation, as shown in this study, we are able to propose that the Uva rosa antica/Quagliano could actually be an ancient grape variety distributed in several part of the Italian peninsula.

The discovered family relationship joins those already found and it is interesting especially because it relocates the belonging of a wine grapes variety previously considered specific of some alpine valleys in the north-east of Italy and of southern France. This observed genotype reshuffling strengthens the view that most of the modern cultivated grapevine varieties have been obtained over the millennia starting from a limited number of ancestors (This et al. 2006).

\section{Conclusions}

Molecular markers analysis, nuclear and chloroplast microsatellites, has revealed that the Uva rosa antica/ Quagliano is the progenitor of no less than three southern autochthonous grapevine varieties, among these stands the well known Uva di Troia. Since the family is composed of three autochthonous sibling and two parents of vague origin, the legendary provenance from the city of Troy in Anatolia are certainly disowned because it is very unlikely been introduced in Italy together with the whole family, let alone by an epic hero. The existence of this family moves at least three centuries back the presence of Uva rosa antica/Quagliano in the south of Italy. Additionally, this family point out the genetic proximity or limited genetic diversity of modern cultivated grapevine. The preservation of the existing biodiversity and the recovery of ancient cultivars is a key point 


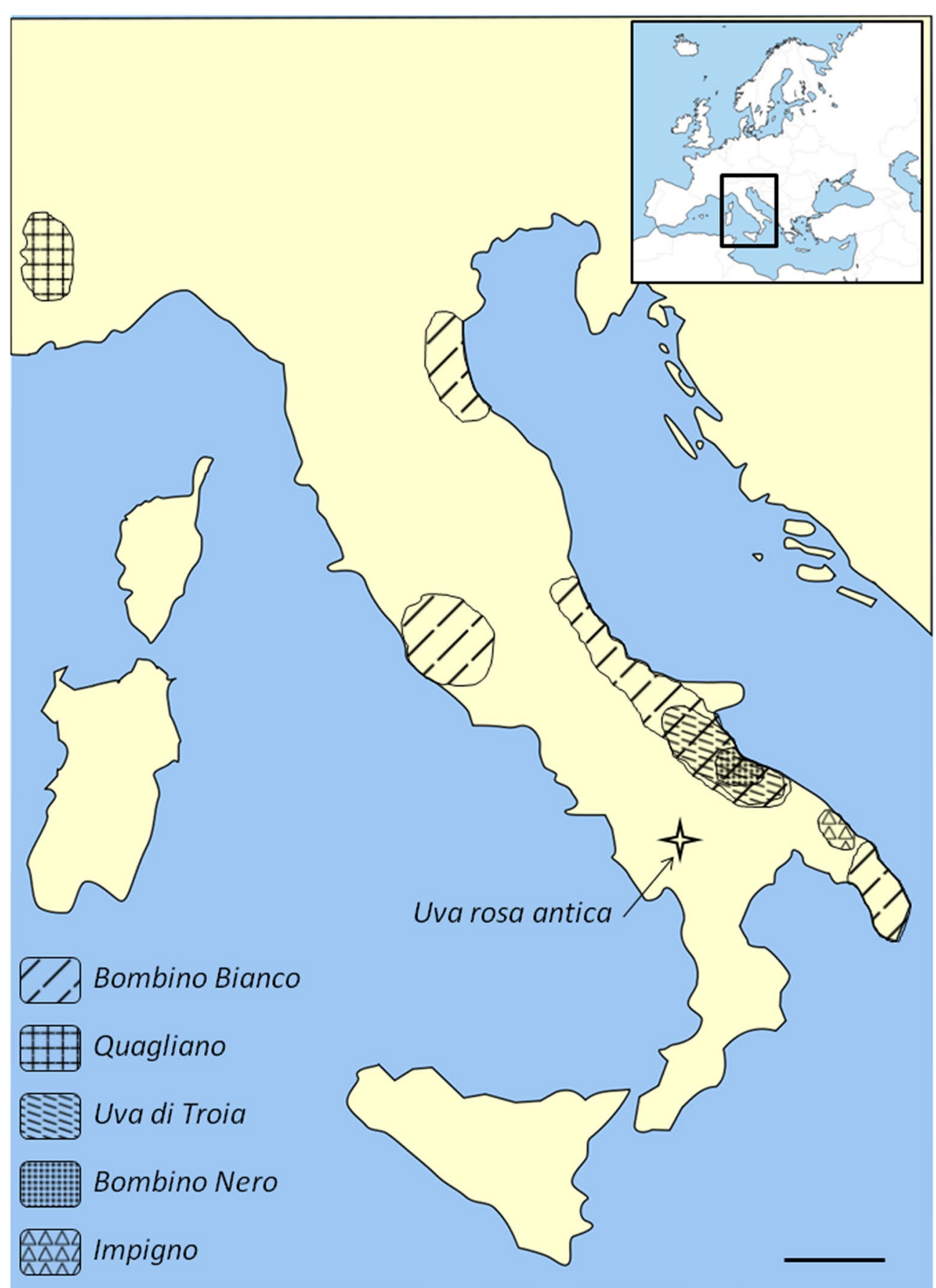

Fig. 3 Geographical distribution. This map represent the Italian peninsula; it shows the geographical distribution of areas of certified and protected production of wines (DOC) from the cultivars under study. These varieties are certainly much more spread but there is no other reliable source for tracing their cultivation in other areas. Scale bar $100 \mathrm{~km}$

for the scientific research, whereas the molecular marker analysis can allow to clarify the evolutionary history of the current varieties especially these varieties that have major features in terms of oenological quality: reconstructing their history could be useful to understand how these favorable characteristics are genetically determined in order to plan later improvements.

\section{Authors' contributions}

$C B, R C P, A R C$ and DA designed the research and wrote the paper; $C B, M G$ performed genotypings; CB and MFC analyzed the data and interpreted the 
results; RcP performed ampelographic and ampelometric analysis. RsP and ARC searched and retrived biodiversity. All authors read and approved the final manuscript.

\section{Author details}

${ }^{1}$ Consiglio per la ricerca in agricoltura e l'analisi dell'economia agrariaCREA - Unità di ricerca per l'uva da tavola e la vitivinicoltura in ambiente mediterraneo, Research Unit for Viticulture and Enology in Southern Italy, Via Casamassima, 148,70010 Turi, BA, Italy. ${ }^{2}$ Consiglio per la ricerca in agricoltura e l'analisi dell'economia agraria- CREA - Centro di ricerca per l'orticoltura, Via Cavalleggeri, 25, 84098 Pontecagnano, SA, Italy.

\section{Acknowledgements}

This work was supported in part by "Basivin Sud" project financed by ALSIAAgenzia Lucana di Sviluppo e di Innovazione in Agricoltura and in part by the Italian Ministry of University and Research-MIUR (PON "R\&C"-2007-2013Project ONEV-cod.00134/2011)

\section{Competing interests}

The authors declare that they have no competing interests.

Received: 26 April 2016 Accepted: 6 September 2016 Published online: 14 September 2016

\section{References}

Acerbi G (1825) Delle viti italiane C-XIX-2-LR. Silvestri, Milano

Arroyo-García R, Ruiz-García L, Bolling L, Ocete R, López MA, Arnold C, Ergul A, Söylemezoğlu G, Uzun HI, Cabello F, Ibáñez J, Aradhya MK, Atanassov A, Atanassov I, Balint S, Cenis JL, Costantini L, Goris-Lavets S, Grando MS, Klein BY, McGovern PE, Merdinoglu D, Pejic I, Pelsy F, Primikirios N, Risovannaya V, Roubelakis-Angelakis KA, Snoussi $H_{\text {, }}$ Sotiri P, Tamhankar S, This P, Troshin L, Malpica JM, Lefort F, MartinezZapater JM (2006) Multiple origins of cultivated grapevine (Vitis vinifera L. ssp. sativa) based on chloroplast DNA polymorphisms. Mol Ecol 15:3707-3714

Bacilieri R, Lacombe T, Le Cunff L, Di Vecchi-Staraz M, Laucou V, Genna B, Péros JP, This P, Boursiquot JM (2013) Genetic structure in cultivated grapevines is linked to geography and human selection. BMC Plant Biol 13:25

Bergamini C, Caputo AR, Gasparro M, Perniola R, Cardone MF, Antonacci D (2013a) Evidences for an alternative genealogy of 'Sangiovese'. Mol Biotechnol 53:278-288

Bergamini C, Cardone MF, Anaclerio A, Perniola R, Pichierri A, Genghi R, Alba V, Forleo LR, Caputo AR, Montemurro C, Blanco A, Antonacci D (2013b) Validation assay of p3_VVAGL11 marker in a wide range of genetic background for early selection of stenospermocarpy in Vitis vinifera L. Mol Biotechnol 54:1021-1030

Bowers JE, Dangl GS, Vignani R, Meredith CP (1996) Isolation and characterization of new polymorphic simple sequence repeat loci in grape (Vitis vinifera L.). Genome 39:628-633

Bowers J, Boursiquot JM, This P, Chu K, Johansson H, Meredith C (1999a) Historical genetics: the parentage of chardonnay, gamay, and other wine grapes of northeastern France. Science 285:1562-1565

Bowers JE, Dangl GS, Meredith CP (1999b) Development and characterization of additional microsatellite DNA markers for grape. Am J Enol Viticult 50:243-246

Bruni A (1844) Cenno su lo stato attuale dell'agricoltura di Barletta, delle modificazioni a farvisi, e delle piante indigene che vi si trovano. Coster, Napoli

Bryan GJ, McNicoll J, Ramsay G, Meyers RC De, Jong WS (1999) Polymorphic simple sequence repeat markers in chloroplast genomes of Solanaceous plants. Theor Appl Genet 99:859-867

Chung SM, Staub JE (2003) The development and evaluation of consensus chloroplast primer pairs that possess highly variable sequence regions in a diverse array of plant taxa. Theor Appl Genet 107:757-767

Cipriani G, Marrazzo MT Di, Gaspero G, Pfeiffer A, Morgante M, Testolin R (2008) A set of microsatellite markers with long core repeat for grape (Vitis spp.) genotyping. BMC Plant Biol 8:127
Cipriani G, Spadotto A, Jurman I Di, Gaspero G, Crespan M, Meneghetti S, Frare E, Vignani R, Cresti M, Morgante M, Pezzotti M, Pe E, Policriti A, Testolin R (2010) The SSR-based molecular profile of 1005 grapevine (Vitis vinifera L.) accessions uncovers new synonymy and parentages, and reveals a large admixture amongst varieties of different geographic origin. Theor Appl Genet 121:1569-1585

Costacurta A, Germinario A (2010) I vitigni storici pugliesi e le DOC collegate. In: Calò A, Bertoldi Lenoci L (eds) Storia regionale della vite e del vino-le Puglie. Edizioni Pugliesi, Martina Franca, pp 629-650

Dakin EE, Avise JC (2004) Microsatellite null alleles in parentage analysis. Heredity 93:504-509

De Lucretiis G (1791) Trattato della piantagione delle viti e delle cause della disposizione dè vini a corrompersi e inacidirsi nella Puglia daunia. Porcelli, Napoli

Del Gaudio S, Giusto D (1965) Impigno. Roma: Annali della Sperimentazione Agraria

Di Rovasenda G (1877) Saggio di un Ampelografia universale. E.Loescher, Torino

Emanuelli F, Lorenzi S, Grzeskowiak L, Catalano V, Stefanini M, Troggio M, Myles S, Martinez-Zapater JM, Zyprian E, Moreira FM, Grando MS (2013) Genetic diversity and population structure assessed by SSR and SNP markers in a large germplasm collection of grape. BMC Plant Biol 13:39

Gasparro M, Caputo AR, Bergamini C, Crupi P, Cardone MF, Perniola R, Antonacci D (2013) Sangiovese and its offspring in southern Italy. Mol Biotechnol 54:581-589

Lacombe T, Boursiquot JM, Laucou V Di, Vecchi-Staraz M, Peros JP, This P (2013) Large-scale parentage analysis in an extended set of grapevine cultivars (Vitis vinifera L.). Theor Appl Genet 126:401-414

Luterbacher J, Dietrich D, Xoplaki E, Grosjean M, Wanner H (2004) European seasonal and annual temperature variability, trends, and extremes since 1500. Science 303:1499-1503

McGovern PE (2004) Ancient wine: the search for the origins of viniculture. Princeton University Press, Princeton

Merdinoglu D, Butterlin G, Bevilacqua L, Chiquet V, Adam-Blondon AF, Decroocq S (2005) Development and characterization of a large set of microsatellite markers in grapevine (Vitis vinifera L.) suitable for multiplex PCR. Mol Breed 15:349-366

Molon G (1906) Ampelografia, vol II. Edizioni Hoepli, Milano, pp 1012-1014

Myles S, Boyko AR, Owens CL, Brown PJ, Grassi F, Aradhya MK, Prinsg B, Reynoldsb A, Chiah JM, Wareh D, Bustamanteb CD, Buckler ES (2011) Genetic structure and domestication history of the grape. Proc Natl Acad Sci USA 108:3530-3535

Robinson J, Harding J, Vouillamoz J (2013) Wine grapes: a complete guide to 1,368 vine varieties, including their origins and flavours. Penguin, Harmondsworth

Sefc KM, Regner F, Turetschek E, Glössl J, Steinkellner H (1999) Identification of microsatellite sequences in Vitis riparia and their applicability for genotyping of different Vitis species. Genome 42:367-373

Sefc KM, Lopes MS, Lefort F, Botta R, Roubelakis-Angelakis KA, Ibáñez J, Pejic I, Wagner HW, Glössl J, Steinkellner H (2000) Microsatellite variability in grapevine cultivars from different European regions and evaluation of assignment testing to assess the geographic origin of cultivars. Theor Appl Genet 100:498-505

Soldavini C, Stefanini M, Dallaserra M, Policarpo M, Scheinder A (2009) SuperAmpelo, a software for ampelometric and ampelographic description in Vitis. In: Acta Hortic: IX international conference on grape genetics and breeding, vol 827

This P, Lacombe T, Thomas MR (2006) Historical origins and genetic diversity of wine grapes. Trends Genet 22(9):511-519

Thomas MR, Scott NS (1993) Microsatellite repeats in grapevine reveal DNA polymorphisms when analysed as sequence-tagged sites (STSs). Theor Appl Genet 86:985-990

Wagner HW, Sefc KM (1999) IDENTITY 1.0. Centre for Applied Genetics, University of Agricultural Sciences, Vienna

Weising K, Gardner RC (1999) A set of conserved PCR primers for the analysis of simple sequence repeat polymorphisms in chloroplast genomes of dicotyledoneous angiosperms. Genome 42:9-19

Zulini L, Russo M, Peterlunger E (2002) Genotyping wine and table grape cultivars from Apulia (Southern Italy) using microsatellite markers. Vitis 41(4):183-187 